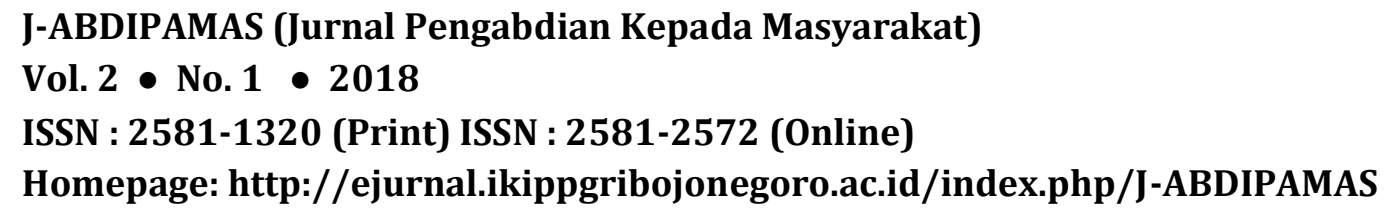

\title{
OPTIMALISASI NILAI-NILAI KEBANGSAAN MELALUI PROGRAM BELA NEGARA DI SMK PGRI PAGAR ALAM
}

\author{
Ramanata Disurya ${ }^{1}$, Suryati $^{2}$, Ermini $^{3}$, Sri Husnulwati ${ }^{4}$, Layang Sardana ${ }^{5}$, Sri Wahyuningsih ${ }^{6}$ \\ 1Universitas PGRI Palembang. Email: ramanatadisurya25@gmail.com \\ 2Universitas PGRI Palembang. Email: suryatilasnai@gmail.com \\ 3Universitas PGRI Palembang. Email: selvaldae@gmail.com \\ 4Universitas PGRI Palembang. Email: srihusnulwati05@gmail.com \\ 5Universitas PGRI Palembang. Email: layangsardana@gmail.com \\ 6Universitas PGRI Palembang. Email: wsri7896@gmail.com
}

\begin{abstract}
The objectives of PkM are (1) the students can understand and identify the thoughts that can deny and erode the love of the homeland and the values of nationality so that it can be anticipated and carried out the prevention of its spread. (2) there is a community group that cares and optimally conducts the association in the framework of implementation of national values through state defending efforts. This PkM activity was conducted in the form of socialization / counseling during the day with the number of participants amounted to 60 students of class XII in SMK PGRI Pagar Alam. The method used in conducting this PkM activity is by lecture method, discussion, and question and answer. The results obtained during the PkM activity was an increase in student's understanding of national values and preliminary state defense program of $73 \%$ when viewed the comparison of the results of the pre test and post test.
\end{abstract}

Keywords: optimization, nationality, state defending

\begin{abstract}
ABSTRAK
Tujuan PkM adalah (1) siswa dapat memahami dan mengidentifikasi pemikiran-pemikiran yang dapat mendangkalkan serta mengikis rasa cinta tanah air dan nilai-nilai kebangsaan sehingga dapat diantisipasi serta dilakukan pencegahan penyebarannya. (2) terdapat kelompok masyarakat yang peduli serta secara optimal melakukan perkumpulan dalam rangka implementasi nilai-nilai kebangsaan melalui upaya bela negara. Kegiatan PkM ini dilaksanakan dalam bentuk sosialisasi/penyuluhan selama sehari dengan banyaknya peserta berjumlah 60 orang siswa kelas XII di SMK PGRI Pagar Alam. Metode yang digunakan dalam melaksanakan kegiatan PkM ini adalah dengan metode ceramah, diskusi, dan tanya jawab. Hasil yang diperoleh selama kegiatan PkM yaitu adanya peningkatan pemahaman siswa terhadap nilai-nilai kebangsaan dan program pendahuluan bela negara sebesar $73 \%$ jika dilihat perbandingan dari hasil pre test dan post test.
\end{abstract}

Kata kunci: optimalisasi, kebangsaan, bela negara 


\section{PENDAHULUAN}

Perkembangan teknologi informasi memang memiliki banyak dampak positif terhadap peningkatan kualitas hidup masyarakat. Akan tetapi, merupakan hal yang wajar jika dibalik banyaknya dampak positif, terdapat juga dampak negatif yang turut serta dalam perkembangan teknologi informasi.

Salah satu dampak positif tekonologi informasi adalah mudahnya memperoleh informasi mengenai semua hal yang ingin diketahui. Begitu pun hal yang mengikutinya, akibat dari teknologi dapat memuat segala macam informasi maka paradigma pemikiran yang mendangkalkan kecintaan terhadap tanah air pun dapat dengan mudah diperoleh dari media sosial.

Pemikiran akan menjadikan seseorang memiliki orientasi untuk melakukan hal-hal yang dipikirkan, begitu juga dengan pendangkalan nilai-nilai kebangsaan akan membuat jati diri masyarakat indonesia perlahan terkikis. Upaya pendangkalan nilai-nilai kebangsaan telah teridentifikasi oleh masyarakat, hingga akhirnya terbentuklah program bela negara. Sebagaimana telah tertuang dalam peraturan perundangundangan yang berlaku di Indonesia, diantaranya sebagai berikut:

1. Undang-Undang Dasar 1945 pada Pasal 30 tertulis bahwa "Tiap-tiap warga negara berhak dan wajib ikut serta dalam usaha pembelaan negara." dan " Syarat-syarat tentang pembelaan diatur dengan undang-undang." Jadi sudah pasti mau tidak mau kita wajib ikut serta dalam membela negara dari segala macam ancaman, gangguan, tantangan dan hambatan baik yang datang dari luar maupun dari dalam.

2. Tap MPR No.VI Tahun 1973 tentang konsep Wawasan Nusantara dan Keamanan Nasional.

3. Undang-Undang No.29 tahun 1954 tentang Pokok-Pokok Perlawanan Rakyat.

4. Undang-Undang No.20 tahun 1982 tentang Ketentuan Pokok Hankam Negara RI. Diubah oleh Undang-Undang Nomor 1 Tahun 1988.

5. Tap MPR No.VI Tahun 2000 tentang Pemisahan TNI dengan POLRI.

6. Tap MPR No.VII Tahun 2000 tentang Peranan TNI dan POLRI.

7. Amandemen UUD 1945 Pasal 30 dan pasal 27 ayat 3.

8. Undang-Undang No.3 tahun 2002 tentang Pertahanan Negara.

Berkaca dari Ringkasan Laporan Koordinasi Strategis Penyususnan Rencana Aksi Strategis Nasional (Stranas) disebutkan bahwa gejala pengikisan nilai-nilai kebangsaan juga tengah terjadi secara gradual berupa sikap egoisme kelompok yang berlebihan, memaksakan kehendak dalam menyalurkan pandangan dan keinginan, bahkan sikapsikap tidak toleran dalam berwacana di kalangan kaum terpelajar telah menjadi pemandangan sehari-hari Indonesia. Kondisi ini sejalan dengan semakin terkikisnya nilai-nilai budaya musyawarah dan kekeluargaan yang menjadi identitas bangsa Indonesia. Ini menunjukan adanya persoalan wawasan dan pengikisan karakter kebangsaan dan jati diri bangsa Indonesia yang dirumuskan dalam Pancasila.

Sebagaimana uraian yang telah diberikan pada halaman sebelumnya, bahwa saat ini nilai kebangsaan semakin dangkal dan terkikis. Sasaran dari pengikisan nilai-nilai kebangsaan serta cinta tanah air adalah masyarakat muda yang sedang menggebu dalam proses pencarian jati diri sehingga mudah untuk dimasuki dengan pikiran-pikiran yang 
tidak sesuai dengan nilai kebangsaan Indonesia. Untuk mengantisipasi hal ini terus terjadi dan semakin berkembang, maka dilakukan sosialisasi mengenai nilai-nilai kebangsaan melalui bela negara di SMK PGRI Pagar Alam.

\section{METODE PELAKSANAAN}

Kegiatan pengabdian kepada masyarakat ini dilaksanakan di SMK PGRI Pagar Alam, dengan alamat Jalan Mayor Jendral S. Parman, No. 28, Beringin Jaya, Pagar Alam Utara, Ulu Rurah, Pagar Alam Selatan, Kota Pagar Alam, Sumatera Selatan 31528 pada hari Senin, tanggal 26 Maret 2018 dengan peserta siswa-siswi kelas XII SMK PGRI Pagar Alam yang berjumlah 60 orang.

Rancangan mekanisme pelaksanaan kegiatan PkM ini dilakukan dengan mengadopsi langkah-langkah action research yang terdiri dari 4 (empat) tahapan, yaitu: perencanaan, tindakan, observasi dan evaluasi, serta refleksi. Kegiatan-kegiatan atau aktivitas-aktivitas dari masing-masing tahapan adalah sebagai berikut.

\section{1) Perencanaan}

Kegiatan-kegiatan yang dilakukan pada tahap perencanaan adalah:

a) Pembentukan dan pembekalan Kelompok Masyarakat Bela Negara

Tim pelaksana diundang untuk mengadakan pertemuan persiapan pelaksanaan dengan melibatkan LPPkMK Universitas PGRI Palembang. Tim pelaksana kemudian diberikan pembekalan mengenai maksud, tujuan, rancangan mekanisme program PKM, dan beberapa hal teknis berkaitan dengan metode/teknik pelaksanaan.

b) Penyusunan program sosialisasi

Berdasarkan hasil identifikasi, hasil analisis permasalahan yang ada, hasil analisis kebutuhan, dan hasil analisis potensi, selanjutnya disusun program sosialisasi.

\section{2) Tindakan}

Tindakan dalam kegiatan ini berupa implementasi Program. Kegiatan-kegiatan yang dilakukan dalam implementasi program adalah (a) pembentukan kelompokkelompok siswa bela negara (b) identifikasi pengetahuan dan pemahaman awal siswa tentang nilai-nilai kebangsaan dan rasa cinta tanah air serta bela negara (c) sosialisasi bahaya laten dari pengikisan dan pendangkalan rasa cinta tanah air.

\section{3) Observasi dan Evaluasi}

Observasi dilakukan terhadap proses diskusi yang berjalan antar masyarakat dalam kelompok anak bela negara yang dibentuk. Instrumen yang digunakan berupa catatan lapangan. Beberapa hal yang diobservasi adalah kendala-kendala, kekurangan-kekurangan, dan kelemahan-kelemahan yang muncul dalam proses di lapangan maupun dalam proses penggunaan di masyarakat. Evaluasi dilakukan terhadap kuantitas dan kualitas diskusi yang dihasilkan. Evaluasi secara kuantitatif dilakukan melalui perbandingan dari jawaban siswa terkait pertanyaan di awal (pre test) dan pertanyaan di akhir (post test). Sedangkan evaluasi secara kualitatif dilakukan melalui diskusi yang terarah pada setiap sesi pemaparan. 


\section{4) Refleksi}

Refleksi dilakukan terhadap kegiatan yang telah dilaksanakan. Hal ini dilakukan semata-mata untuk mengetahui kekurangan-kekurangan atau kelebihan-kelebihan terhadap kegiatan-kegiatan yang telah dilakukan dalam rangka untuk menetapkan rekomendasi terhadap keberlangsungan atau pengembangan kegiatan-kegiatan berikutnya.

\section{HASIL DAN PEMBAHASAN}

Hasil yang dicapai melalui kegiatan PKM ini dituangkan dalam bentuk hasil kegiatan pada setiap tahap pelaksanaan sebagai berikut

\section{Perencanaan}

Kegiatan-kegiatan yang dilakukan pada tahap perencanaan adalah sebagai berikut. a. Pembentukan dan pembekalan kelompok diskusi siswa

Pelaksanaan tahap ini didahului dengan mengundang tim pelaksana untuk mengadakan pertemuan persiapan pelaksanaan dengan melibatkan LPPkMK Universitas PGRI Palembang.

b. Penyusunan program sosialisasi

Berdasarkan hasil identifikasi, hasil analisis permasalahan yang ada, hasil analisis kebutuhan, dan hasil analisis potensi sekolah, selanjutnya disusun program pelatihan. Pelaksanaan sosialisasi dilakukan selama 1 hari tatap muka, dengan peserta siswa/i di SMK PGRI Pagar Alam.

\section{Pelaksanaan Tindakan}

Tindakan dalam kegiatan ini berupa implementasi Program.Kegiatan-kegiatan yang dilakukan dalam implementasi program adalah sebagai berikut. (a) Pembentukan kelompok-kelompok diskusi siswa, (b) Identifikasi pengetahuan dan pemahaman awal siswa mengenai nilai-nilai kebangsaan melalui program bela negara, (c) Pembinaan dan sosialisasi program bela negara.

\section{Observasi dan Evaluasi}

Observasi dilakukan terhadap proses diskusi siswa yang berlangsung. Evaluasi dilakukan terhadap kuantitas dan kualitas diskusi yang berlangsung. Dari hasil observasi yang dilakukan, diketahui bahwa rata-rata siswa belum mengetahui tentang program pendahuluan bela negara serta bagaimana aplikasi program bela negara di sekolah. Hal ini diketahui dari pertanyaan-pertanyaan yang muncul saat sosialisasi berlangsung. Selain itu, evaluasi yang perlu dilakukan adalah perlunya peningkatan terkait pelatihan dasar-dasar bela negara terhadap siswa dengan waktu yang lebih terukur.

\section{Refleksi}

Refleksi dilakukan terhadap kegiatan yang telah dilaksanakan. Hal ini dilakukan semata-mata untuk mengetahui kekurangan-kekurangan atau kelebihan-kelebihan terhadap kegiatan-kegiatan yang telah dilakukan dalam rangka menetapkan rekomendasi terhadap keberlangsungan atau pengembangan kegiatan-kegiatan berikutnya. Hasil refleksi adalah perlu dilakukan suatu upaya untuk membantu 
meningkatkan penguasaan guru terhadap nilai-nilai kebangsaan melalui program bela negara.

Pengabdian Kepada Masyarakat dilakukan dengan baik dan sesuai dengan rencana yang ditetapkan oleh tim. Berdasarkan hasil observasi awal yang dilakukan tim PkM didapat bahwa rata-rata siswa belum memahami tentang makna bela negara. Hal ini terlihat dari jawaban-jawaban saat wawancara dilakukan oleh tim PkM pada siswa SMK PGRI Pagaralam.

Hasil observasi awal inilah yang menjadi rujukan tim PkM menentukan tujuan dan materi sosialisasi. Setelah didapat hasil observasi awal, tim PkM kemudian mengajukan semacam pre test (sebanyak 3 pertanyaan uraian) pada siswa terkait pemahaman mereka mengenai nilai kebangsaan dan bela negara. Dari 60 orang siswa sebanyak 7 $(11,7 \%)$ orang siswa dapat menguraikan dengan baik pertanyaan pertama mengenai nilai kebangsaan. Untuk soal kedua, sebanyak 11 siswa (18,3\%) dapat menjelaskan dengan baik pengetahuan mereka mengenai program bela negara. Sedangkan pada pertanyaan ketiga, hanya 3 orang siswa (3,3 \%) yang mengetahui bagaimana penerapan program bela negara di sekolah.

Tim PkM kemudian melakukan sosialisasi yang dilakukan oleh 6 (enam) orang dosen dengan materi yang terkait nilai-nilai kebangsaan dan program pendahuluan bela negara, dan ditutup dengan materi mengenai aplikasi program bela negara di sekolah. Dalam sesi sosialisasi ini, siswa juga diberikan kesempatan untuk mengajukan pertanyaan pada setiap sesi pemaparan materi. Sosialisasi cenderung berlangsung aktif, hal ini terlihat dari pertanyaan-pertanyaan yang diajukan oleh para siswa.

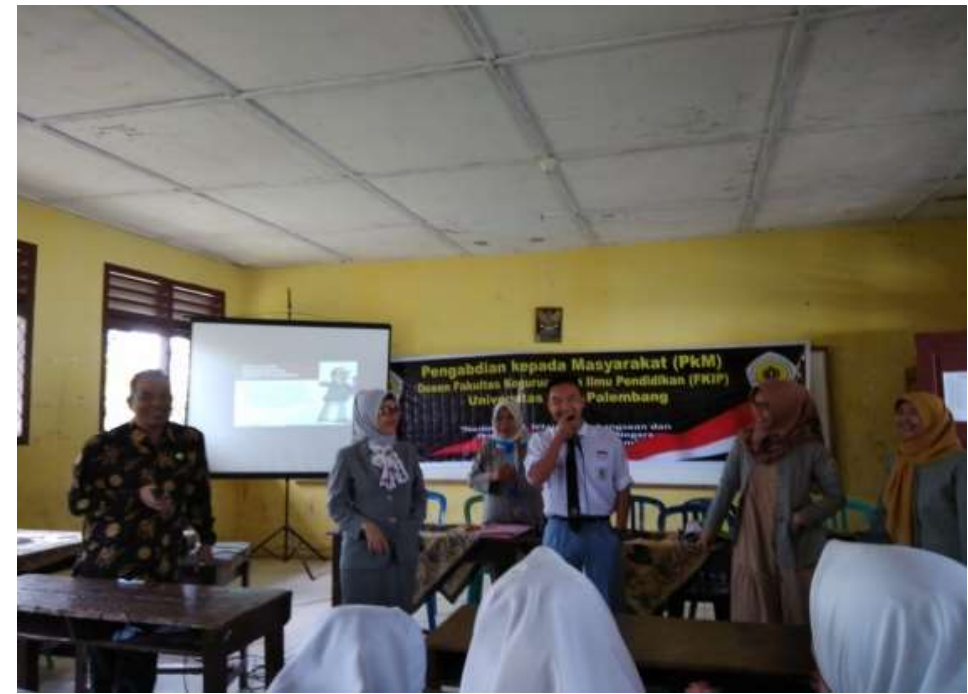

Gambar 1. Peserta sedang menjawab pertanyaan yang diberikan oleh Tim PkM

Setelah dilakukan sosialisasi, tim PkM kemudian melakukan semacam post test (dengan 3 pertanyaan uraian) kepada siswa untuk mengetahui sejauh mana pemahaman siswa mengenai materi yang telah disampaikan. Dari post test ini kemudian didapat hasil bahwa sebanyak 55 siswa (91,6 \%) dapat menjelaskan mengenai nilai-nilai kebangsaan walaupun belum lengkap. Untuk pertanyaan kedua, sebanyak 51 orang siswa (85 \%) dapat menjelaskan dengan baik pemahaman mereka mengenai program bela negara. Sedangkan untuk pertanyaan ketiga sebanyak 45 orang siswa (75 \%) dapat 
menjelaskan bagaimana aplikasi program bela negara dalam kehidupan sehari-hari. Selengkapnya mengenai hasil pre test dan post test dapat dilihat pada tabel 1.

Tabel 1. Hasil Evaluasi Pengetahuan Siswa Terkait Nilai-Nilai Bela Negara

\begin{tabular}{|c|c|c|c|}
\hline \multicolumn{2}{|c|}{ Hasil Jawaban } & \multirow{2}{*}{ Peningkatan } & \multirow{2}{*}{$\begin{array}{c}\% \\
\text { Peningkatan }\end{array}$} \\
\hline Pre Test & Post Test & & \\
\hline 7 & 55 & 48 & 80,0 \\
\hline 11 & 51 & 40 & 66,7 \\
\hline 2 & 45 & 43 & 71,7 \\
\hline \multicolumn{2}{|c|}{ Rata-rata } & 44 & 73 \\
\hline
\end{tabular}

Jika merujuk hasil pre test dan post test yang ada, maka secara kuantitatif diperkirakan terjadi peningkatan rata-rata sebanyak $73 \%$ terkait pemahaman siswa terkait nilai-nilai kebangsaan dan program pendahuluan bela negara melalui sosialisasi ini. Walaupun hal ini masih harus dibuktikan dengan penelitian lanjut.

\section{PENUTUP}

Berdasarkan hasil pengabdian kepada masyarakat dan pembahasan yang telah diuraikan pada halaman sebelumnya, maka dapat disimpulkan 1) Rata-rata siswa di SMK PGRI Pagaralam belum memiliki pemahaman terkait nilai-nilai kebangsaan dan program pendahuluan bela negara, hal ini terlihat dari observasi awal serta hasil pre test, 2) Setelah dilakukan sosialisasi, siswa mulai memiliki pemahaman mengenai nilainilai kebangsan dan program bela negara. Hal ini terlihat dari hasil post test yang menunjukan pemahaman terkait materi sosialisasi. 3) Jika merujuk nilai kasar atas nilai pre test dan post test, secara kuantitatif terjadi peningkatan pemahaman sebesar $\pm 90 \%$. Pelaksanaan sosialisasi, partisipasi, dan motivasi peserta sudah berjalan dengan baik. Namun demikian, berdasarkan hasil pelaksanaan yang telah dilaksanakan maka disarankan Perlu kiranya dilakukan program pengabdian dengan waktu yang lebih lama serta metode pengukuran yang lebih baik, agar dapat terukur secara kuantitatif dan baik secara kualitas pengabdian.

\section{UCAPAN TERIMA KASIH}

Tim PkM mengucapkan terima kasih pada (1) Universitas PGRI Palembang yang telah memberikan bantuan dana DIVA Universitas PGRI Palembang, dan (2) LPPkMK Universitas PGRI Palembang yang telah memfasilitasi kegiatan PkM.

\section{DAFTAR PUSTAKA}

Direktorat Jendral Potensi Pertahanan. (2015). Tataran Dasar Bela Negara. Jakarta: Kementrian Pertahanan Republik Indonesia.

Tim Penyusun. (1945). Undang-Undang Dasar 1945 pada pasal 30. Jakarta.

Tim Penyusun. (1973). Tap MPR No.VI Tahun 1973 tentang konsep Wawasan Nusantara dan Keamanan Nasional. Jakarta. 
Disurya, Optimalisasi Nilai-Nilai....39

Tim Penyusun. (1954). Undang-Undang No.29 tahun 1954 tentang Pokok-Pokok Perlawanan Rakyat. Jakarta.

Tim Penyusun. (1982). Undang-Undang No.20 tahun 1982 tentang Ketentuan Pokok Hankam Negara RI. Diubah oleh Undang-Undang Nomor 1 Tahun 1988. Jakarta.

Tim Penyusun. (2000). Tap MPR No.VI Tahun 2000 tentang Pemisahan TNI dengan POLRI. Jakarta.

Tim Penyusun. Tap MPR No.VII Tahun 2000 tentang Peranan TNI dan POLRI. Jakarta.

Tim Penyusun. Undang-Undang No.3 tahun 2002 tentang Pertahanan Negara. Jakarta. 
40 J-Abdipamas, Vol. 2, No. 1 April 2018 